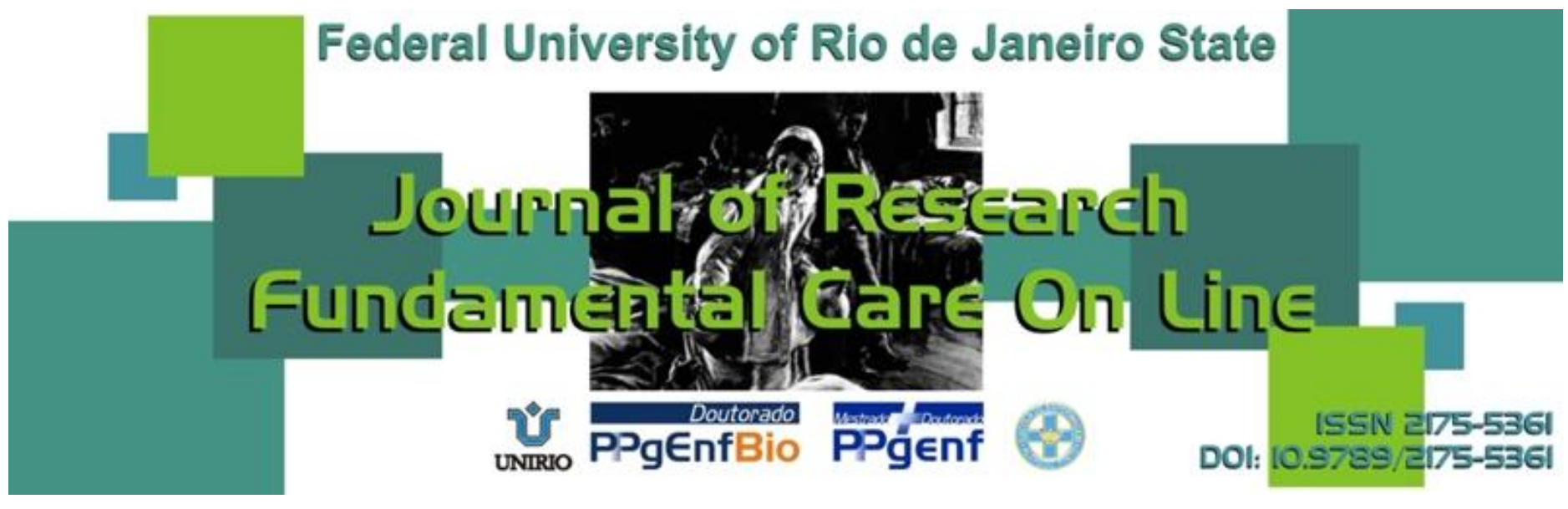

\title{
RESEARCH
}

\section{DIFFICULTIES EXPERIENCED BY WOMEN UNDERGOING TREATMENT FOR BREAST CANCER}

\section{DIFICULDADES VIVENCIADAS POR MULHERES EM TRATAMENTO PARA O CÂNCER DE MAMA}

LAS DIFICULTADES EXPERIMENTADAS POR LAS MUJERES QUE RECIBEN TRATAMIENTO PARA EL CÁNCER DE MAMA

Ana Cármem Pisoni ${ }^{1}$, Adriane Cristina Bernat Kolankiewicz ${ }^{2}$, Juliane Scarton ${ }^{3}$, Marli Maria Loro ${ }^{4}$, Marina Mazzuco de Souza ${ }^{5}$, Cleci de Lourdes Schmidt Piovesan Rosanelli ${ }^{6}$

\begin{abstract}
Objective: To identify difficulties experienced by women with breast cancer undergoing cancer treatment. Method: A qualitative descriptive study, developed with women with breast cancer undergoing some form of cancer treatment, receiving care at a Center for High Complexity in Oncology - CACON a hospital in the northwest of the state of Rio Grande do Sul. To collect data we used open interview. Results: There were difficulties in impaired self-image, side effects, prejudice, social rejection and physical limitations, which aroused feelings of sadness, hopelessness, despair, but the maintenance of life prevails in the face of difficulties and these are support in God. Conclusion: These results enable assist health professionals and families in coping with these difficulties, because they need professional support, family and friends. Descriptors: Breast neoplasms, Women, Body image.
\end{abstract}

\section{RESUMO}

Objetivo: Identificar dificuldades vivenciadas por mulheres com câncer de mama em tratamento oncológico. Método: Estudo qualitativo, descritivo, desenvolvido com mulheres com neoplasia de mama submetidas a alguma modalidade de tratamento oncológico, assistidas em um Centro de Alta Complexidade em Oncologia - CACON de uma instituição hospitalar do Noroeste do Estado do Rio Grande do Sul. Para a coleta de dados utilizou-se entrevista aberta. Resultados: Evidenciaram-se dificuldades no comprometimento da autoimagem, efeitos colaterais, preconceito, rejeição social e as limitações físicas, o que despertou sentimentos de tristeza, desesperança, desespero, mas a manutenção da vida prevalece diante das dificuldades e essas encontram apoio em Deus. Conclusão: Estes resultados possibilitam auxiliar profissionais de saúde e familiares no enfrentamento destas dificuldades, pois estas necessitam de apoio profissional, familiar e de amigos. Descritores: Neoplasias de mama, Mulheres, Imagem corporal.

\section{RESUMEN}

Objetivo: Identificar las dificultades que experimentan las mujeres con cáncer de mama en tratamiento de cáncer. Método: Estudio descriptivo cualitativo, desarrollado con las mujeres con cáncer de mama sometidas a algún tipo de tratamiento contra el cáncer, que reciben atención en un Centro de Alta Complejidad en Oncología - Cacon un hospital en el noroeste del estado de Rio Grande do Sul. Recoger datos se utilizó la entrevista abierta. Resultados: No hubo dificultades para efectos autoimagen, laterales con discapacidad, los prejuicios, el rechazo social y las limitaciones físicas, que despertó sentimientos de tristeza, desesperanza, desesperación, pero el mantenimiento de la vida prevalece en medio de las dificultades y estos son apoyarnos en Dios. Conclusión: Estos resultados permiten ayudar a los profesionales de la salud y las familias para hacer frente a estas dificultades, ya que necesitan apoyo profesional, la familia y amigos. Descriptores: Cáncer de mama, Las mujeres, La imagen corporal.

${ }^{1}$ Nursing oncology specialist/UNIJUI. ${ }^{2}$ Nursing. Master in Public Helth. Phd in Sciences from the Federal University of São Paulo (UNIFESP). Teacher, Departament of Life Sciences (DCVida) Northwest Uniniversity of Rio Grande do Sul (UNIJUI).-mail: Adriane.bernat@unijui.edu.br. ${ }^{3}$ Nursing Student of the ${ }^{9}$ th semester UNIJUI. E-mail: juliane.scarton@unijui.edu.br. ${ }^{4}$ Nursing. Master of Science in Education. PhD in Nursing/UNIFESP/SP. Professor of Life DC UNIJUI. E-mail: marlil@unijui.edu.br. ${ }^{5}$ Academic Course of Nursing UNIJUI. Scholarship Program Institution Balls Scientific Initiation (PIBIC). E-mail: marina.mazzuco@unijui.edu.br. ${ }^{6}$ Enfermeira. Master of Science in Education. PhD in Nursing / UNIFESP / SP.Teacher of (DC Life)/UNIJUI. E-mail: cleci.rosanelli@unijui.edu.br. 


\section{INTRODUCTION}

The word cancer is considered a great villain, because generally people associate with death. For women breast cancer is the villain, since it affects a much valued female body, which plays a significant role in the motherhood, sexual and imaging.

Breast cancer remains the second most frequent type of cancer in the world and ranks first among that affect women. In Brazil, it is the most common type of cancer and is the leading cause of mortality among women. According to the Ministry of Health $(\mathrm{MOH})$, the number of new cases in 2012, in the country is 52,680 ; as compared to mortality in 2008 were 12,098, and 11,969 women and 129 men. ${ }^{2}$

The etiology of breast cancer involves an interaction of several factors as risk factors and by means of epidemiological and clinical observation may be associated with the likelihood of developing cancer of the mammary gland with the presence of these variables. ${ }^{3}$

Risk factors determine the groups of people exposed to a greater likelihood of developing breast cancer, and should be examined more carefully and frequently. The factors that are proven by scientific research are age, family history, history of benign proliferative diseases, and prolonged exposure to endogenous estrogens, exposure to ionizing radiation, obesity and postmenopausal. Already as apparent, are considered explained by a majority of studies: nulliparity, hormone replacement therapy and use of hormonal contraceptives. ${ }^{3}$

It is known that the early detection of breast lump is still the most efficient way to obtain satisfactory prognosis and treatment. The practice of self-examination is very important and critical to the detection; it is easily understood and accessible to women, often shows up as a strong weapon against the disease, preventing the mutilation of the breasts through mastectomy and up even death of the patient. ${ }^{4}$

Breast cancer must be addressed by a multidisciplinary team aimed at integral treatment of patients. Therapeutic modalities that are currently available are: surgery, radiotherapy for loco-regional cancer chemotherapy and hormone therapy for systemic treatment. ${ }^{4}$

Mastectomy is the surgical treatments most feared by women, leading to feelings of sadness, shame and often depression. The surgery changes the body image and sexual brings repercussions and can pass on their daily lives, triggering symptoms such as depression and anxiety, because surgery carries with it an aggressive character and traumatizing for a woman's life, leading to disfigurement and consequently the a modification of the self-image. ${ }^{4}$

Chemotherapy is the most common treatment used and is in a group of drugs that act at different stages of cell division, affecting all cells, causing side effects such as asthenia, fatigue, nausea, vomiting, fatigue that can often compromise adherence to treatment, leading to the abandonment of this. ${ }^{5}$ All these factors are causing discomfort, stress and suffering and possible prolonged hospitalization. ${ }^{6}$

Mastectomy either partial or radical is one of the treatments that most women with breast cancer are submitted. It interferes with the physical, emotional and social, as ultimately results in mutilation of a region of the body that arouses sexual desire and libido. This process interferes with sexuality, self-image and the 
Pisoni AC, Kolankiewicz ACB, Scarton J et al.

feminine aesthetic, today emphasized and highly valued by society. Besides this dimension which symbolizes sexuality, her tits are still related to the important role of motherhood, because these produce milk to represent the livelihood of the first months of life of any human being. ${ }^{4}$

Radiotherapy is a method capable of destroying tumor cells, using beams of ionizing radiation is administered to the body externally, applied locally, its principle is interfering with molecules of deoxyribonucleic acid (DNA), ionizing radiation blocking cell division and determine the destruction tumor. ${ }^{7}$ Its toxic effects are limited to an area of skin, irritation or mild skin burns, inflammation of mucous membranes, hair or hair loss in the irradiated areas and a decrease in the count of the blood cells are some of the most common side effects of radiotherapy. ${ }^{7}$

Given this range of changes that can be experienced during cancer treatment the objective of this study was to: Identify the difficulties experienced by women with breast cancer undergoing cancer treatment.

\section{METHODOLOGY}

This is a qualitative research, descriptive, developed women with breast cancer undergoing some form of treatment for cancer, assisted in a Center for Highly Complex Oncology - CACON of a General Hospital in the Northwest region of the State of Rio Grande do Sul.

Data collection was conducted through structured interviews, using guiding question: "Tell me what are the difficulties experienced from the completion of treatment for cancer."

The interviews were conducted in the aforementioned institution in September 2011, in a single room, paying attention to preserve the comfort and privacy of interviewees in order to avoid interruptions of any kind. The interviews were audio - tape, transcribed, categorized and analyzed.

J. res.: fundam. care. online 2013. jul./set. 5(3):194-01
Difficulties experienced...

The analysis and interpretation of the data of this study followed the methodological guidelines indicated by Minayo $^{8}$ proposing first ordering the data, which was carried out transcription, the reading of the material, as well as the organization of reports and data observed in the field. After the classification performed via the junction of the information in accordance with the similarity data through thorough and repeatable reading of the information collected. Finally we carry out the final analysis, when we establish links between them and the acquired theoretical, seeking to answer the research questions through the designed purpose.

The study included 10 female patients who met the following inclusion criteria: patients diagnosed with breast cancer in cancer treatment.

Survey participants were identified by the letter $\mathrm{E}$ followed by the sequential number of the interview which corresponds to the E1 E10 to preserve anonymity. For delineation of the sample, we used the method of data saturation.

The sampling saturation is a conceptual tool often used in qualitative research reports in different areas in the field of Health, among others. Still is used to establish or close the final size of a sample under study, disrupting the uptake of new components. ${ }^{9}$

Concerning the characterization of individuals, ages ranged from 30-53 years in relation to marital status, the majority is married (70\%) and all underwent surgical oncology treatment and / or radiotherapy and / or chemotherapy. The study complied with the ethical aspects, in accordance with Resolution 196/96.

\section{RESULTS AND DISCUSSION}

From the reading and rereading the interviews were grouped information by convergences of ideas resulting in an analytical category. The category is about the difficulties 
Pisoni AC, Kolankiewicz ACB, Scarton J et al.

experienced by women with breast cancer undergoing treatment for cancer.

\section{Difficulties experienced by women with breast cancer treatment}

After the diagnosis of breast cancer, women face different situations, primarily the impact of the diagnosis which leads to many negative thoughts, considering that most of the time the cancer has poor prognosis depending on the phase that was detected. Often need to go through surgical treatment which leads to the possibility of change in body image, limitations and possible consequences of adjuvant to surgery. ${ }^{4}$

Changes and changes likely because of the treatment must be addressed by the patient, their family and social support, as part of everyday life. As can be seen in the speech of the interviewee:

Everything changes, because you are no longer the same person, have barriers to be overcome (E10).

Given these barriers need to be overcome are the side effects of chemotherapy, which to be a systemic treatment can have adverse effects such as alopecia, anxiety, nausea, vomiting, fatigue, renal and digestive. These effects vary from patient to patient depending on the type and combination of drugs.

Hair loss or alopecia varies in intensity depending on the drug used and according to the person under treatment. Can occur throughout the body but is most common in the head, in some people there is no hair loss, but it can change color and texture. ${ }^{7}$

It is one of the side effects of chemotherapy, which can bring more suffering more than the surgery itself, as in the social context, hair loss shows different, not beautiful, the diseased person unquestionably, reinforcing the feeling of compassion felt by and others by the patient herself and culturally it is normal for females to display long hair and beautiful, a fact J. res.: fundam. care. online 2013. jul./set. 5(3):194-01

\section{Difficulties experienced...}

that hinders the acceptance of alopecia both the woman and the society. ${ }^{10}$ Accordingly, health professionals can prepare the patient for chemotherapy and coping with side effects. The presentations below come from meeting with the authors emphasize:

Hair loss was very significant for me and my family because my husband looked at me and said "she will lose all the hair (E1).

Hair loss was too bad, because I deal with hair; I had long hair blonde [...] (E2).

From the hair loss was all going down (E5).

Chemotherapy can cause hair fall. This fall is variable depending on the drug used and the patient. It can get on average three weeks after the start of chemotherapy. This is because the hair root has a large number of multiplying cells and these are attacked by drugs that are circulating in the blood.

The hair loss showed significant fact for these women, despite these feelings, respondents found support their families. The family support is extremely important at this time because it can help women accept their condition, become participatory in self-care and disease prevention, as well as in verbalizing their feelings.

The family ends up being the main source of support for the patient, the caregiver may be a spouse, other family members and close friends. Concern for the family caregiver and quality of care are essential, as they will have important effect on costs for both the system and the family, since the preparation of caregivers leads to decreased medical demands and costs of hospital demand. ${ }^{11}$

The family must actively participate in confronting these difficulties, leading her to have feelings of courage and hope. The emotional support of children happens through gestures of acceptance, affection, care and help. Regarding mate, there is a direct relationship between the marital relationship. It is extremely important the 
man's participation in the treatment and resumption of conjugal life. ${ }^{12}$

My husband wanted to go until shaves the hair is the same as mine, so I said I did not need to because I knew that it would not grow and my [...] (E5).

Another side effect of chemotherapy is fatigue preventing the patient to perform daily activities. The tension caused by the disease, the frequent visits to the treatment center to receive medication and treatment effects are factors that contribute to fatigue causing fatigue.

In this study fatigue was also prevalent as the lines below:

\begin{abstract}
I have a hard time doing things, really, washing clothes I almost cannot, I do like giving, then I put the clothes in the machine, then centrifuge, takes cobwebs, now cannot get well sorry too tired [....] (E10).

You have a number of limitations, not weight bearing (I8).

At home also changed, because before I did everything, now is not the same anymore, so need to test your limits, you tire much the same $(\mathrm{E} 1)$.
\end{abstract}

Some people with cancer eventually develop the disease at some point or treatment, signs and symptoms related to fatigue in that sense it is important to identify these causes and intervene with strategies for alleviating the symptom, it is a common and treatable symptom but interferes significantly the quality of life of these patients. ${ }^{13}$

Also mastectomy in women causes a feeling of loss that displeases his identity, finds him grotesquely modified by removal of the breast or part, by the symbolic character attributed to the heavy emphasis on breast cancer, because it represents femininity. ${ }^{14}$ The reports of some women allow you to observe the feelings of sadness, despair, frustration, difficulty of acceptance with this new reality:

After the surgery I felt ... because we look in the mirror, sees that there is a breast that gives something (E6).
Because if we think, departs from that body there [...] when we ta, an outfit boot, all right, but the time to take a bath, we get [...] the time that you will go front of the mirror, God forbid, gives the panic, panic you see [...] (E7).

The breasts make up the feminine aesthetic and the removal of the breast, usually in women causes a feeling of mutilation causing a great shaking in body image, because the breast is the symbol of femininity, some interviewees even became emotional when answering interview.

Despite these feelings of mutilation demonstrated by several women can realize that life, healing prevails, being much more important than having both breasts, as shown by the speech below:

Mama, I [...] at the beginning was bad, but now, I'm happier with a breast, when I had the two [...] because I know in a few days I'll restore, will look good [...] (E2).

We believe that the initial process after mastectomy is the generator of negative feelings and after preparation of this process women can vibrate with survival.

Breast cancer arouses different reactions and feelings with people in general, therefore, to society, is a stigmatizing disease, and may frighten those who are faced with a carrier of this disease. It may possibly explain the expulsion of people, somehow expressing the difficulty of dealing with a situation that threatens to life.10 disease.

Prejudice, social rejection are the causes of embarrassment for women with mastectomies, which further complicates the face of this experience, as shown in the statements below:

You are no longer the same person, have barriers to be overcome, and thus the bias ta lot out there. Because I, before I leave, I had fun, now, do not let you leave, the more I see that people look at us differently (E1).

Not out yet, to the door of my house so quit, but for the street so do not leave [...] For us, it's complicated [...] (E3). 
Pisoni AC, Kolankiewicz ACB, Scarton J et al.

I was so ashamed I left, I was ashamed ... seemed that you get off the street, it seemed that everyone was looking at you, you know as well [...] so strange [...] course, of course, people look at [...] (E5).

Interviewees carry with them the issue of prejudice, as reported difficulties in joining a social network often motivated by the shame they feel because of the absence of the breast.

Social networking refers to structural or institutional dimension associated with an individual, eg, neighborhood, religious organizations, health care and school. Social support has an individual dimension, being constituted by social network members that are actually important to the person. It can be understood as a "web of relationships" that connects individuals who have social ties with each other, allowing resources to support flow through these ties. ${ }^{11}$

The search for spiritual support was reported by some interviewees. Faith gives strength to overcome obstacles and comfort by maintaining hope, and assist in the promotion of individual well-being, giving a sense of security. ${ }^{15}$

While God gives me strength, I'll be here, I'll fight. I think to myself and say to God, my God-force, sometimes I sagging [...] that the Lord helps me, because I'm not alone [...] you know, I believe I could not do it, you do not have God in your heart, you have nothing (E1).

Mainly trust God, ask and give your life to Him [...] (E2).

I asked God to get it right and go straight on (E4).

We have to think a lot about God, and I trust, both in medicine and in God [...] then I ask for God to heal me God (E9).

Patients and family members before the hopelessness and suffering caused by the disease, seek spirituality in a positive direction for life. Care to cancer patients makes - be more complex than other diseases because it involves, in addition to the physical-biological and sociocultural, spiritual aspects of people. ${ }^{16}$ It is up to J. res.: fundam. care. online 2013. jul./set. 5(3):194-01
Difficulties experienced...

the nurse and his staff who are responsible for planning individualized care, understand and appreciate the relationship between spirituality and coping with cancer, the patient's vision.

\section{CONCLUSION}

This study highlighted the difficulties that women face when performing cancer treatment which can be surgery, chemotherapy, radiotherapy or combined.

The woman who is carrying out breast cancer shows a series of feelings and emotions, namely fear, rejection, loss. We identified several difficulties for women, such as the impairment of their self-image due to mastectomy, the side effects of chemotherapy, radiotherapy, especially alopecia, prejudice, social rejection and physical limitations.

The issue of mutilation of the body due to the withdrawal of the breast is partially or totally caused feelings of sadness, hopelessness, despair, but despite all these feelings preservation and maintenance of life prevailed for some, after which the process of development is not mind having only one breast. Seeking support in God is what strengthens them to face everyday.

Therefore these results may help healthcare professionals working with cancer patients to help them in facing these difficulties, including guiding his family on this process that happens after the treatment and these patients require professional support, family and friends, providing the well-being, better $\mathrm{QOL}$, attitudes often simple.

\section{REFERENCES}

1. Lotti RCB, Barra AA, Dias RC, Makluf ASD. Impacto do tratamento de câncer de mama na qualidade de vida. Rev Bras de Cancerologia. 2008, 54(4): 367-371. 
Pisoni AC, Kolankiewicz ACB, Scarton J et al.

2. Brasil. Ministério da Saúde. 2012. Câncer de Mama/Detecção Precoce. [acessado 2012 Mar 05]. Disponível em http://www2.inca.gov.br/wps/wcm/connec t/tiposdecancer/site/home/mama/detecca o_precoce.

3. Bonfim IM, Almeida PC, Araújo IMA, Barbosa ICFJ, Fernándes AFC. Identificando fatores de risco e as práticas de autocuidado para detecção precoce do câncer de mama em familiares de mastectomizadas. Rev Rede de Enfer do Nordeste. 2009, 10(1):1165.

4. Silva $C B$, Albuquerque $V$, Leite J. Qualidade de Vida em Pacientes Portadoras de Neoplasia Mamária Submetidas a Tratamentos Quimioterápicos. Rev Bras de Cancerologia. 2010, 56(2): 227-236.

5. Gonçalves LLC, et al. Mulheres com Câncer de mama: Ações de auto cuidado durante a quimioterapia. Rev. Enferm. UERJ. 2009, 17(4): 575-580.

6. Pedro ENR, Funghetto SS. Concepções de cuidado para os cuidadores: um estudo com criança hospitalizada com câncer. Rev Gaúcha Enferm. 2005, 26(2): 210-9.

7. Genç F, Tan M. Symptoms of Patient With Lung Cancer Undergoing Chemotherapy and Coping Strategies. Cancer Nursing ${ }^{\mathrm{TM}}$. 2011, 34(6): 503-509.

8. Minayo MCS. Pesquisa social: teoria, método e criatividade. Petrópolis, RJ: Vozes. 2008, $27^{\mathrm{a}}$ ed.

9. Fontanella BJB, Ricas J, Turato ER. Amostragem por saturação em pesquisas J. res.: fundam. care. online 2013. jul./set. 5(3):194-01
Difficulties experienced...

qualitativas em saúde: contribuições teóricas. Cad. Saúde Pública. 2008, 24(1): 17-27.

10. Pereira SG, Rosenhein DP, Bulhosa MS, Lunardi VL, Lunardi Filho WD. Vivências de cuidados da mulher mastectomizada: uma pesquisa bibliográfica. Rev Bras Enferm. 2006, 59(6): 791-5.

11. Sanchez KOL, Ferreira NMLA, Dupas G, Costa DB. Apoio social à família do paciente com câncer: identificando caminhos e direções. Rev Bras Enferm. 2010, 63(2): 290 9.

12. Vasconcelos PM, Neves JB. Importância do apoio familiar à mulher submetida à cirurgia para tratamento da Neoplasia Mamária. Rev Enferm Integrada. 2010, 3(1): 422-432.

13. Gorini MIPC, Silva PO, Chaves PL, Ercole JP, Cardoso BC. Registro do diagnóstico de enfermagem fadiga em prontuários de pacientes oncológicos. Acta Paul Enferm. 2010, 23(3): 354-8.

14. Gasparelo C, Sales CA, Marcon SS, Salci MA. Percepções de mulheres sobre a repercussão da mastectomia radical em sua vida pessoal e conjugal. Cienc Cuid Saude. 2010, 9(3): 535-542.

15. Tavares JSC, Trad LAB. Estratégias de enfrentamento do câncer de mama: um estudo de caso com famílias de mulheres mastectomizadas. Rev Ciênc e Saúde Col. 2010, 15(1): 1349-1358.

16. Guerrero GP, Zago MMF, Sawada NO, Pinto MH. Relação entre espiritualidade e 
Pisoni AC, Kolankiewicz ACB, Scarton J et al. Difficulties experienced... câncer: perspectiva do paciente. Rev Bras

Enferm. 2001, 64(1): 53-9.

Received on: 06/06/2012

Reviews required: 18/01/2013

Approved on: 01/01/2013

Published on: 01/07/2013 